\title{
A "Family Project" to fight Usher, a rare disease leading to deaf-blindness
}

\author{
Steffen Suchert \\ From 5th European Conference on Rare Diseases (ECRD 2010) \\ Krakow, Poland. 13-15 May 2010
}

It was 1994 when physicians told us, that our two sons - deaf from birth - will lose their eye sight also to Usher, a rare genetic disease. With inspiring support from motivated scientists, private equity, National- and European Agencies we moved from fragmented basic research in identifying the gene, the molecular mechanisms of the protein and the specific mutation to shared objectives in disease specific research for a therapy. We founded a Family-Foundation to finance our activities, a medical device company to develop a retina implant, a chip for the eye and worked in EU- and US organisations to bring science ahead, e.g. the Foundation Fighting Blindness (FFB), Fondation Voir \& Entendre, Pro Retina Foundation. We have already identified a cellbased treatment by a drug which, down the road, has the potential to put on hold the progression of our son's disease.

Therefore we have focused our activity with a view to strengthening research with the European TREATRUSH project within FP-7 Health, participated in networks for fund-raising and pursued tests to see, if the drug (PTC 124) will stop the degeneration process in the retina with the assumption that what works in Duchenne disease will also work in Usher $1 \mathrm{C}$, and raise awareness of companies to invest in therapy with PTC 124 for patients with nonsense mutations in retinal degenerative diseases including Usher 1C. Unlike the early days we see a clear road to a therapy and are planning clinical trials with interdisciplinary teams. There is also a critical mass of expertise and substantial management by a biotech company for the benefit of all with Usher 1C. Yes, we can.

Correspondence: info@suchert.eu

FAUN-STIFTUNG, Postfach 1194 02, 90104 Nürnberg, Germany
Published: 19 October 2010

doi:10.1186/1750-1172-5-S1-010

Cite this article as: Suchert: A "Family Project" to fight Usher, a rare disease leading to deaf-blindness. Orphanet Journal of Rare Diseases 2010 5(Suppl 1):010.
Submit your next manuscript to BioMed Central and take full advantage of:

- Convenient online submission

- Thorough peer review

- No space constraints or color figure charges

- Immediate publication on acceptance

- Inclusion in PubMed, CAS, Scopus and Google Scholar

- Research which is freely available for redistribution

Submit your manuscript at www.biomedcentral.com/submit
C Biomed Central 